\title{
The Singing 'Vice': Music and Mischief in Early English Drama $^{1}$
}

'Debates about music are not about nothing.'2

Over the last half-century, scholars have extensively studied and debated the use and function of instrumental and vocal music in the English mystery plays, ${ }^{3}$ but music in the secular English interlude drama has yet to receive similar treatment. ${ }^{4}$ This is not without good reason: the subject of music in the interludes is fraught with ambiguity and uncertainty. Although the extant interludes contain many indications of song in the form of references, snatches, cues, stage directions, and even full song texts, very little scored music has been preserved in either manuscript or print. ${ }^{5}$ Richard Rastall's observation with regard to music in early English religious drama might also be made of music in the interludes: 'the surviving written music is only a fraction of that actually required in performance'. ${ }^{6}$ To be sure, absent musical scores and elided stage directions present special problems for the researcher. Thus, very sensibly, discussions of music in secular interlude drama have tended to limit themselves to those rare play texts that contain significant music in score, such as John Rastell's The Four Elements and Ulpian Fulwell's Like Will to Like. ${ }^{7}$ As Richard Rastall further notes, since documentation is quite scarce 'informed guesswork is the only way forward' in discussions of music in early English drama, 'although the word "informed" is one that needs to be stressed'. ${ }^{8}$ Suzanne Westfall observes that 'entertainments in great households were almost always occasional, ephemeral and frequently nontextual due to their multi-mediality. Consequently, they are extremely difficult to recover without some documentation such as visual representation, musical score, or some description of movement and dance'.?

Amidst non-textuality and the resulting shortage of extant scores to serve as documentation of musical activity, even the most restrained speculative approach still leads to the conclusion that music and musicians were crucial 
both to the emergence of the interlude as a genre of household entertainment and in the actual performance of interludes. Arguably, the musicality of late medieval and early modern English drama derives from the presence of minstrels among players. In addition to physical comedy, tumbling, dancing, tricks, improvisation, singing, and instrumental performance, the minstrel repertoire included acting and recitation. To be successful in their craft, both itinerant and liveried minstrels had to be versatile performers; a similar versatility was also required of the actor-singers who played the Vice - the flamboyantly transgressive mischief-maker frequent in secular English interlude drama. ${ }^{10}$

Although the term 'interlude' remains contested, by the early Tudor period interludes were typically short plays performed by troupes of four to six players - often termed 'interluders' - who worked under the auspices of the court, noble households, and even ecclesiastical households. ${ }^{11}$ Interlude performances would frequently have occurred in the great hall, often as part of a larger program that might include dining, dancing, musical performance, and other sorts of entertainment. ${ }^{12}$ From a theatrical perspective, the great hall of a household is perhaps best understood as a mixed-use space transformed by the performances - of everyday life and of various entertainments - that occurred within it. These performances would have been heard as well as seen, with the interplay of aurality and visuality within this otherwise ordinary household space heightened by occasions of extraordinary theatricality. Julia Craig-McFeely cautions that 'especially in the modern world, with its privileging of sight, we tend to consider music as sound dissociated from the visual and social space that it occupied, and hence overlook vital aspects of its meaning and purpose'. ${ }^{13}$ As a household entertainment, the dramatic interlude uses music to mediate, both semantically and semiotically, between the performative subjectivity of the 'play' and the concrete objectivity of the 'game'. It is suggestive that by the later Middle Ages the Latin ludus meant 'school' as well as 'stage play' and 'game'; in performance, the Vice's singing circulates through these notions until at last the interlude fully exposes its didactic purpose. But in order for the interlude's hero to be redeemed, he must first be seduced.

\section{'Enter the Vice'}

The rise of the interlude as a dramatic genre is also closely tied to the emergence of the professional player, and, as Peter Happé points out, 'there is 
little doubt that the rise of the common actor occurred at roughly the same time as the disappearance of the itinerant minstrel'. ${ }^{14}$ This 'same time' was a long transitional period during which the performative activities of minstrels and players overlapped. For instance, in Wisdom, an anonymous East Anglian play from the 1460 s, the figures representing the soul's three Mights — Mynde, Wyll, and Understondyng — each call upon players accompanied by 'mynstrallys' to perform dumbshows that enact the several vices of each Might. ${ }^{15}$ Wyll introduces each of his seven vices-of-the-flesh pageant-style as they enter with their 'mynstrell' whom he also announces:

Yowr mynstrell a hornepype, mete,

pat fowll ys in hymselff but to erys swete.

Wyll understands the minstrel and his music to be depraved and grasps music's power to deceive the senses.

Earlier in Wisdom, Mynde, Understondyng, and Wyll sing a three-part song for which neither the text nor the music is supplied; only the stage direction 'et cantant' is provided (620sd). Mynde takes the 'tenowr' part (617), Understondyng takes the 'mene' or middle voice (618), then Wyll claims the remaining part and makes explicit the connection between merry music and mischief:

And but a trebull I owtwrynge,

The Devell hym spede pat myrthe exyled!

Mankind, a moral interlude from the 1470s, also calls for 'mynstrellys' to perform within the play; at one point, Myscheff, the primary Vice, even refers to another Vice, Nought, as a 'mynstrell' and urges him to 'blow' his 'flewte' to announce the devil's entrance (451-53). ${ }^{16}$ Indeed, the putative ontological relationship between minstrelsy and vice had been well established by this time: itinerant minstrels in particular were considered morally deficient figures predisposed to vice and depravity; their slippery social and performative identities combined with their 'mobility' to render them suspect. ${ }^{17}$ Moreover, like minstrels, dramatic Vice figures employed theatrically and socially transgressive manoeuvres in order to cultivate relationships of 'complicity' and 'solidarity' with the great-hall spectators who were often within, and always in close proximity to, the dramatic performance. ${ }^{18}$ In this specialized 
and intimate performance situation, the immediacy of the Vice characters' musical mischief works to seduce the audience as well as the dramatic hero.

In Mankind, Myscheff serves as a sort of master of the Vices' ceremonies, with Nought, Nowadays, and New Gyse comprising a virtual guild of Vices. Together, they move among the 'sers' and collaborate to lure these spectators into singing a song, from which the dramatic hero Mankind abstains (1l. 332 ff.). Nowadays clears the way, then Nought provides the song cue:

$\begin{array}{ll}\text { Nowadays } & \text { Make rom sers, for we have be longe! } \\ & \text { We wyll cum gyf yow a Crystemes songe. } \\ \text { Nought } & \text { Now I prey all pe yemandry pat ys here } \\ & \text { To synge wyth ws wyth a mery chere; }\end{array}$

Nought then supplies his fellow Vices and the audience with a musical prompt; he sings what is probably the first line and the tune of a popular song: 'Yt ys wretyn wyth a colle, yt ys wretyn wyth a cole'. New Gyse, Nowadays, and the spectators then follow Nought's lead and sing the same line: 'Yt ys wretyn wyth a colle, yt ys wretyn wyth a cole'. Now that the tune has been established, Nought introduces the new lyric: 'He pat schytyth wyth his hoyll, he pat schytyth wyth his hoyll', which New Gyse, Nowadays, and the audience then sing. As Rastall observes, 'the deceit of this event is paramount. Since mortals' songs of praise are in imitation of angelic song, the Vices' promise of a "Christmas song" would have borne precisely that implication'. ${ }^{19}$ The Vices have perversely enchanted the audience; in supplying these unexpected words to a familiar tune, the Vices employ sung obscenity - a devilish trait - to coerce the unsuspecting audience into colluding. For this to succeed, the spectators must be tricked in such a way that they will be too stunned to resist the new words they suddenly find themselves singing.

Not only words but also music 'signifies by means of some signifying code ... But no code is originary; there is no single code which is the key to the work, nor is there a code which explains all other codes'. ${ }^{20}$ As Monelle asserts,

the apparent power of a code to explain a piece [or song] may in fact be subverted when the listener realizes that the code is itself part of the surface material governed by other codes. ${ }^{21}$ 
When familiar music combines with new song text, the signs accumulate and produce 'unending codes'. ${ }^{22}$ But when the song is performed by the Vice figure - the embodiment of his own signifying symptom - within the interlude's frame of expectations, the musical code becomes self-governing.

Although the seductive Vice tends to conceal his true nature - which is in fact not nature but artifice - from other dramatic characters, he typically reveals it to the audience or to other Vices; in this performative strategy, 'the personator', namely the actor, 'is not entirely lost in the personated' Vice figure. ${ }^{23}$ Robert Weimann and Douglas Bruster coin the term 'personation' to denote performance practice that 'privileges the making of the mask, the skill and the show of playing the role of another'. ${ }^{24}$ Indeed, the Vice simultaneously foregrounds his performative identity and his musical and acting skills; song, in which the Vice sings about his activities or relishes the mischief he has already wrought, is a frequent vehicle for the Vice's personation. As Happé notes, in the interludes 'there is a strong convention that a group of villains, led ... by the specialist Vice who apparently was often a competent singer, should celebrate their solidarity, depravity, or the accomplishment of their plotting by means of a song. ${ }^{25}$ This convention also demands that the actor-singer who embodies and enacts the Vice render his performative 'competence' visible.

The Vice in his ethopoeia is thus 'a kind of meta-role, defined by its ability to transgress definition, its identity lying in its operating in only provisional identities'. ${ }^{26}$ Ironically, this instability renders unpredictable the driving character in the moral interlude, which is a particularly predictable dramatic genre. When the Vice is at his most transgressive his dramatic identity is the mischief he sets in motion, and in the context of pre- and early-Reformation England the audience understands this mischief to be the devil's work. Although in fifteenth-century English cycle drama the stage devil is frequently accompanied by an entourage of personified sins or vices, by the early sixteenth century, the dramatic devil merges with his own entourage to form the Vice figure. ${ }^{27} \mathrm{~A}$ Vice figure may appear individually or as a sort of deputy to a named devil, or - as in Mankind - as part of a group of Vices. Whether singly or in conspiracy with others, Vice figures set out to wreck the 'social harmony ${ }^{28}$ of the drama by engaging in mischief — including subterfuge, dissimulation, and temptation - that also brings about the seduction of the interlude hero into a single bad act or an entirely bad life. The seduction of the audience extends this wreckage to include spectators as quasi-dramatic characters subject to both influence and transformation. For the audience, 
the Vice's personation resonates simultaneously within immediate performance and within the minstrel-Vice tradition of transgressive representation, which includes seductive musicality.

In his discussion of the use of music by wicked characters in early English religious drama, Richard Rastall points out that 'the Devil and his agents use music - even good music — to beguile a potential victim. This might be called the "seduction" or "deceit" position'. ${ }^{29}$ Since deceit is a component of seduction, the secular interlude Vice may be said to advance the 'seduction' position. Within the drama, song both complements and advances the interlude Vice's seduction project, in which the activities range from benign troublemaking, such as Mery Reporte's manipulative stage-management in John Heywood's comedy A Play of the Wether, to the outright malignant, as in Revenge's incitement to matricide in Pickering's Horestes or Sedycyon's betrayal in Bale's King Johan. The singing Vices in each of these three plays will reappear later in this essay to illustrate both the pattern and the variety of this musico-dramatic phenomenon.

\section{Singing as Seductive Sign}

In his controversial theory of seduction, Jean Baudrillard claims that 'seduction ... never belongs to the order of nature, but that of artifice - never to the order of energy, but that of signs and rituals. ${ }^{30} \mathrm{~A}$ signifying performance becomes a ritual when it is repeated. A sign, such as a voice or a scent, may thus also be a ritual, and a ritual, such as song, may also be a sign. As singular sign or repeated ritual, song in dramatic representation provokes an 'immediate attraction' that puts seduction in motion. ${ }^{31}$ According to Baudrillard, 'because seduction never stops at the truth of signs, but operates by deception and secrecy, it inaugurates a mode of circulation that is itself secretive and ritualistic, a sort of immediate initiation that plays by its own rules'. In this way, 'to be seduced is to be turned from one's truth. To seduce is to lead the other from his/her truth'. ${ }^{32}$ This distraction from truth is the Vice's goal, but to achieve his goal he cannot openly challenge the hero. Although 'challenge and seduction are quite similar ... there is a difference':

in a challenge, one draws the other into one's area of strength ... whereas in a strategy (?) of seduction, one draws the other into one's area of weakness ... To seduce is to appear weak. To seduce is to render weak. We seduce with our weakness, 
never with strong signs or powers. In seduction, we enact this weakness, and this is what gives seduction its strength. ${ }^{33}$

Paradoxically, then, the Vice is both the strongest and the weakest dramatic character in the interlude. The hero's and the audience's 'truth' is a 'social relation' 34 subject to diversion by the Vice, whose misuse of music evinces a moral weakness that softens and seduces the hero and the audience while it also advances the dramatic action toward the didactic conclusion. ${ }^{35}$ The Vice's victory ultimately constitutes his defeat, which is self-defeat. The hero will succumb to the Vice's seduction but be redeemed; in this way the Vice is vanquished, the moral struggle resolved, and the social harmony restored. This reversal, and the consequent ritualization and predictability of the interlude genre, finally expose the Vice's slipperiness. He fails in his program of seduction because 'seduction is immediately reversible, and its reversibility is constituted by the challenge it implies and the secret in which it is absorbed'. ${ }^{36}$ In order to fail at his own goal, the Vice must explicitly reveal his implicit challenge, the recognition of which is the function of the didactic drama. And since the interlude's outcome is already known, the drama must locate its energy in the seducer's performance.

In this performance, the seducer-Vice is always a more engaging, amusing, energetic, and attractive dramatic character than the seduced hero. The Vice's performative mode of song signifies and amplifies his seductive ethopoeia. Certainly, 'songs were a common element in the part of the Vice, for he was able to use them to establish his identity, to show off his cleverness, and, because of his structural role to make significant steps in the development of the play'; ${ }^{37}$ song is indeed instrumental in implementing the Vice's identity as an enchanter of both the audience and the hero. In her discussion of occult magic and theatrical music, Linda Austern points out that 'there are three main categories of musical enchanter in English Renaissance drama, roughly parallel to the categories of rational, irascible, and concupiscible into which The Praise of Musicke divides the soul and the categorical affections of music'. ${ }^{38}$ The Vice figure practices concupiscible enchantment in both his referential functions, which engage the story space, and his performant functions, which engage the theatrical space.

Jean Alter argues that although referential functions and performant functions 'interact' and 'coexist', their 'coexistence does not mean simultaneity'. These two functions are 'mutually exclusive' in their 'tension' and they 'compete, at any given moment, for the attention of performers and spectators'. In 
a theatrical performance, Alter asserts, the 'referential function is carried out with signs that aim at imparting information', but the performant functions 'fall outside the operations of semiosis' ${ }^{39}$ The interlude audience, however, perceives the singing Vice as an undivided sign: the performant actor-singer and the referential character achieve simultaneity. The Vice's metonymicality, moreover, also ensures that the singing Vice and his dramatic descendents — singing clowns and fools — ever fall entirely outside the 'operations of semiosis. 40

Shakespeare's Twelfth Night foregrounds the dual referential and performant semiosis of the Vice's performance. By 1600-1, the likely date of Twelfth Night, the Vice figure had become a resonant dramatic relic. In the text of Twelfth Night, Feste is called 'Feste' only once; in the stage directions he is 'Clowne' and other characters refer to him frequently as 'Foole'. In each case, however, Feste is onomastically his performative type. As the fool-clown, disguised as Sir Topas, Feste collapses the referential and the performant functions when he comments metatheatrically on his own activities, affirming their affinities with those of his performative progenitor, the 'old Vice'. Feste's act 4 exit song is a sign that points back simultaneously to his own earlier mischief in the drama and to the earlier Vice figure's connection to the devil, who also disguises himself and his intentions in order to make mischief. Feste's song and his singing constitute a polyvalent sign:

Malvolio Foole, I'll requite thee in the highest degree. I prethee, be gone.

Clown I am gone, sir, and anon, sir,

Ile be with you againe:

In a trice, like to the old vice,

your neede to sustaine,

Who with dagger of lath, in his rage and his wrath,

Cries ah ha, to the diuell:

Like a mad lad, paire thy nayles, dad,

Adieu good man diuell. Exit

Feste's song production exposes both the actor-singer and the clown he plays: Malvolio now sees Sir Topas's/Feste's true identity in the clown's song/act of singing. While Feste ridicules the histrionics of the Vice's past performance ('his rage and his wrath'), he also enacts them. At once he reveals his actorly ${ }^{42}$ awareness of the mischievous dramatic ritual he embodies by self-referencing the conventionality of his Vice-like exit song, which serves representational 
as well as structural and ritual purposes. With reference to heavenly music in English religious drama, John Stevens claims that the 'point was not to increase dramatic tension or to "soften up" the audience, but representation"; 43 when worldly music is used by naughty dramatic characters, however, this softening-up is in fact being represented. Feste's exit song represents his 'old' vicehood, which resonates through his actorly performance. As Weimann and Bruster point out, 'memories of the Vice are closely related to presentational practice in which performance is displayed in its own right'. 44

If, as Stevens and Rastall suggest, heavenly music represents holiness and heavenliness, then the possibility that worldly music represents corruption and worldliness might also be considered. ${ }^{45}$ Because of the Shakespearean Falstaff's mischief-making and his subversive activities, he has been taken to resemble aspects of the old interlude Vice. ${ }^{46}$ But one more sign of Falstaff's Vice has been overlooked, ${ }^{47}$ namely, his musicality. For example, in the Merry Wives of Windsor, Falstaff peppers his discourse with titles and lines from popular songs first written for not the stage but consumption by the public outside the theatre. ${ }^{48}$ In so doing, Falstaff demonstrates what Adorno terms 'atomistic listening' which produces a concupiscible enchantment that 'loses itself weakly ... in the charm of the moment, the pleasant single sound, the easily graspable and recollectable memory'. 49 Falstaff then uses these graspable and recollectable snatches of popular song to market himself and his seductive project. The 'commodity character' of this popular music is foregrounded by the theatrical frame and through the corrupt workings of Falstaff's 'personality', more specifically, his exuberant seductivity. ${ }^{50}$ Recall as well that in act 2 scene 2 of 1 Henry $I V$ the tricked and humiliated Falstaff threatens to take revenge on $\mathrm{Hal}$, Peto, Poins, and Bardolph not with violence but with song:

Hang thyself in thine own heir-apparent garters! If I be ta'en, I'll peach for this. And I have not ballads made on you all and sung to filthy tunes, let a cup of sack be my poison.

$(2.2 .43-6)^{51}$

Falstaff is describing the way that existing tunes could be transferred among new lyrics for invective purposes. In these cases, the music carried its prior unsavory associations with it into its new verbal context by imparting its own code and significance to the new words. Here, the old ballads will not only retain their originary 'filthy' qualities but will even convey them to the new jigs through which Falstaff plans to mock his friends publicly. ${ }^{52}$ In the actorly 
project of playing Falstaff, the musical code both embeds and evokes such mischief.

Long before Falstaff's engagement with popular song, stage music was perceived to be the worst sort of worldly music. Quintilian, the first-century Roman rhetorician, had expressed anxieties about the capacity of music to seduce - to deceive and to deprave. Quintilian's fragmentary Institutio Oratoria, a widely relied-upon educational text in the Middle Ages, gained even greater authority after a more complete manuscript was discovered in 1416. According to Quintilian, the worst worldly music was seductive stage music of the sort 'prevailing in the theaters and being of an effeminate sort, loaded with lustful notes, [that] has largely excised whatever manliness remained among us. ${ }^{53}$ This gendered pessimism regarding theatrical music combines with the English Reformation's increasing anxieties about any dramatic representation in which actors by 'outward signs' show themselves otherwise than they are. Stephen Gosson argues that by

outward signes, euery man must show him selfe outwardly to be such as in deed he is. Outward signes consist eyther in words or gestures, to declare our selues by wordes or by gestures to be otherwise then we are, is an act executed where it should not, therefore a lye. 54

According to Gosson, theatrical spectacle is a seductive 'lie' that effects a disruptive misrepresentation and invites the devil's attention:

The diuel is not ignorant how mightely these outward spectacles effeminate and soften the hearts of men, vice is learned with beholding, sense is tickled, desire pricked, and those impressions of mind are secretly conueyed ouer to the gazers, which the plaiers do counterfeit on the stage. As long as we know our selues to be flesh, beholding those examples in Theaters that are incident to flesh, wee are taught by other mens examples how to fall. And they that came honest to a play, may depart infected. ${ }^{5}$

Contemporary treatises also display anxiety about the seductive power of stage music. In his Apologia musices (1588), John Case condemns the use of music in the theatre, and the otherwise encomiastic Praise of Musicke (anonymous, 1586) displays 'suspicion of [the] unchasteness and incontinency' theatrical music might cause in the listener/spectator. ${ }^{56}$ The authors of these treatises perceive the theatrical use of both instrumental and vocal music to be a misuse 
and a cause for moral alarm. In the double context of sixteenth-century drama and music, it is important to remember that, as Leppert notes,

Music's pleasures and relevance have never been denied. Indeed, music's most virulent enemies have often condemned music, or some music, precisely for the pleasures it provides and the effects of its audition on the social fabric. ${ }^{57}$

Ironically, as a theatrical genre the moral interlude seeks to circumscribe and control immoral social impulses by first representing these impulses in enchanting and entertaining ways. Music is essential to this representation.

\section{When is a text a song?}

In the extant texts of Tudor interlude drama the absence of scored music does not prove the absence of song in a dramatic situation where singing might be otherwise expected or indicated. The same may be said of Shakespeare's plays. As Duffin points out, in Twelfth Night no stage direction appears before 'I am Gone Sir' in the First Folio to indicate 'that this is a song rather than spoken verse, but [since] the text is separated like other songs in the First Folio and is assigned to Feste' it is probably meant to be sung. ${ }^{58}$ Indeed, renowned and reliable Shakespearean editors supply a stage direction for Feste to sing at this point. ${ }^{59}$ What is more, not only is the text of 'I am Gone Sir' set apart from the foregoing dialogue but the prosody of this text is markedly different from that of the surrounding dialogue; the song shows a variation in meter and rhyme characteristic of songs for which stage directions are explicit throughout the First Folio. ${ }^{60}$ Further, 'because of the opening's parting aspect' Duffin sets 'I am Gone Sir' to the tune of 'O Sweet Oliver', which is sung by Touchstone in As You Like It (F) 3.3. ${ }^{61}$ This 'parting aspect' that Duffin observes emphasizes Feste's Vice heritage and renders the likelihood of his singing at this moment a virtual certainly.

As Weimann and Bruster observe, 'bodily performance and literary language helped constitute the agencies of clowns and fools'. ${ }^{62}$ Another element that both constitutes and signifies the agency of the Vice-fool-clown is that figure's musical production in the form of song. Singing embeds agency when, as Tia DeNora notes, 'it is perceived as incorporating into itself and/or its performance some property of the extra-musical, so as to be perceived as doing the thing to which it points'. DeNora continues: 
Thus, music is much more than a structural 'reflection' of the social. Music is constitutive of the social in so far as it may be seen to enter action and/or conception when 'things' take shape in relation to music ... or when actors employ musical structures as models or analogies for elaborating conceptual awareness. ${ }^{63}$

The property of the extra-musical is the Vice-actor's performative identity. Feste's exit song further provides a musical structure as a model for Shakespeare's audience to elaborate its own conceptual awareness of the 'old' Vice's role. The clown's explicit auto-analogy establishes his referential function as the seductive yet atavistic 'old Vice' simultaneously with his double performant function as Olivia's household minstrel and as the singer in the hereand-now of his own performance.

Wapull's interlude The Tyde Taryeth no Man presents a music-text-performance dilemma similar to that of 'I am Gone Sir'. ${ }^{64}$ The text of Tyde Taryeth assigns two songs to the Vice 'Courage', in which Courage leads a group of deputy Vices, namely, Feigned Furtherance, Painted Profit, and Hurtful Help. No musical score is provided in the play text. The texts which are marked as songs — 'First Courage causes Minds of Men' (B1v) and 'We have great gain with little Pain' (D4) — are set apart and rhymed differently from the play's rhymed-couplet speeches. Including the refrain, 'First Courage' has the rhyme scheme of ababcc, and 'We have Great Gain' rhymes ababccdeed. Except for the rhyme-royal Prologue and Courage's entrance the rest of the play is in rhymed couplets of uneven length, although mostly pentameter. Courage's entrance is composed of uneven short lines, mostly of four to seven syllables, with the rhyme scheme of aabccb. The speech is also set in columns, unlike the rest of the play text. Although the stage directions do not specifically call for a song here, and no musical score is provided, the Vice Courage's entrance speech is probably a song, as the clown Feste's exit speech almost certainly is.

\section{John Heywood and Musical Improvisation in the Interlude}

Although the early morality plays represent abstracted vices as polar opposites to virtues, the first dramatic character named 'Vyce' appears as the mischievous Mery Reporte in John Heywood's comic interlude The Play of the Wether. ${ }^{65}$ John Heywood (1497-c 1577) may be best understood as the last in the long tradition of the court minstrel: a versatile musician, composer, player, and playwright, he composed and performed lute songs for Henry 
VIII, Edward VI, and Mary I. Under Henry VIII, Heywood was the only person listed as 'synger' in the extant household payment records, ${ }^{66}$ where he appears regularly from 1519 to 1555; the record suggests that Heywood was pensioned in $1557 .{ }^{67}$ Contemporary testimony also confirms that Heywood was a court virginalist. ${ }^{68}$ Married to Thomas More's niece, son-in-law to the printer-lawyer-playwright John Rastell, and grandfather of the poet John Donne, John Heywood had a long court career interrupted only by his brief imprisonment in 1543, probably for denying the Royal Supremacy which he seems to have accepted in the following year. An otherwise staunch Catholic, Heywood went into exile in 1564 to live with his son, a Jesuit priest in Antwerp. Heywood died around 1577.

At the court of Henry VIII, John Heywood seems to have had the status of something like an allowed fool. His Catholicism emerges only very obliquely in his plays; Bevington maintains that A Play of the Wether is a plea for religious reconciliation in the midst of the gathering storm of Henry's divorce crisis. ${ }^{69}$ Although Wether is certainly a comedy, the play presents two serious themes, namely, the reconciliation of opposing social interests and the growing problem of which suitors should be allowed access to King Henry. ${ }^{70}$ Prior to Henry VII, the king of England had been considered a 'first among equals' and he circulated freely among his court, but, as Fiona Kisby points out,

the sovereign was now the sole centre of power and focal point of control. Consequently, access to him was jealously guarded. This development had an impact on the organization and architectural layout of the royal houses. Most now contained an inner sanctum of private rooms in which the king spent an increasing amount of time and to which access was controlled. ${ }^{71}$

In 1528, Heywood was appointed a 'Sewer of the King's Chamber'. In his new position, he would have acted as a sort of usher in the king's Chamber; as such he would have witnessed the struggles for access to the king and the presentation of numerous and conflicting suits, both valid and absurd. Heywood's 'familiarity with Chamber procedures is evident in the text' of Wether as well. ${ }^{72}$ While sewers had their access to the Privy Chamber strictly limited, the 'evidence hints that this sometimes may have been a passport to musical activities there. ${ }^{73}$ So, in a typological reading of Wether, Jupiter - to whom the various characters bring their suits for different types of weather favourable to their various activities — would be Henry VIII. Such a reading further suggests that the Vice 'Mery Reporte', who ushers the suitors about 
and controls their access to Jupiter, would originally have represented, and been played by, Heywood himself.

Given John Heywood's accomplishments in composing both poetry and music - accomplishments Stevens ranks among those of Heywood's better known musical contemporaries Banastir, Cornysh, Barclay, Redford, and Rhodes $^{74}$ — a reading of Heywood's plays seems to reveal a rather astonishing lack of both instrumental music and song. If the extant play texts are to be believed, Heywood's Johan Johan and The Pardoner and the Friar (both c 1529) are entirely without music. There are at least three plausible explanations for this: first, that the musical entertainments took place around rather than within the interlude's performance; ${ }^{75}$ second, that the musical parts were written, ${ }^{76}$ rehearsed, and stored separately from the play texts and have been lost; ${ }^{77}$ or, third, that as composer, lyricist, playwright, musician, and performer Heywood improvised and thus had no need to write his own musical part into his play. As Strohm asserts,

we all know how written music can exist in the mind without ever appearing on paper - it can be composed, rehearsed, performed, taught and transmitted all by memory ... The structure of music and what people do with it are thus two different things, and history is generally more interested in what people do; thus the question is not so much 'written or unwritten music' as 'to write or not to write music'. ${ }^{78}$

In light of this perspective, and in the unique case of John Heywood, the third possibility is perhaps the most persuasive.

Stevens notes that in England, unlike in Italy, 'there could hardly have been a tradition of courtier poets singing extempore ... without its having left some traces'. ${ }^{79}$ As it happens, such traces were left by the only 'synger' of Henry VIII's royal household, John Heywood. Henry VIII certainly appreciated music; his actual musical talents may be in dispute, but the records do show that he rewarded excellent musicians and dismissed mediocre ones. ${ }^{80}$ According to Heywood's assistant Thomas Whythorne, who studied virginals, lute, and verse-making under Heywood at court for more than three years, Heywood

was not only very well skilled in music, and playing on the virginals but also such an English poet, as the like, for his wit and invention, with the quantity that he wrote, was not as then in England, nor before his time since Chaucer's time. ${ }^{81}$ 
And Whythorne was equally keen as a social observer. At the moment when minstrelsy was on the wane and a new conception of professional literate musicianship was on the rise, Whythorne was himself particularly anxious to be regarded as a musician, rather than counted among the 'rascal[s] and off-scum of that profession, who be, or ought to be, called minstrels (though nowadays many do name themselves musicians)' ${ }^{82}$

Already by the late 1540s Heywood's peers regarded him as a musician, not a minstrel; indeed, by this time on the continent 'composers ... were no longer considered "mere" makers or craftsmen'. ${ }^{83}$ In Scriptorium 2 (1548), John Bale refers to Heywood as 'Orpheus alter, instrumentorum studiosus, musica et poeta'; further, 'a musical manuscript containing some of Heywood's poems belonged to a musical circle centering on St. Paul's', and two lute-songs attributed to Heywood have been identified in the British Library. ${ }^{84}$ The lutesong 'Why soo unkende' in Henry VIII's MS (RA 58 f.6) is likely Heywood's composition as well. In fact, Stevens believes that Henry VIII's MS as a whole constitutes 'a professional musician's commonplace-book' and speculates that as such it would probably have been John Heywood's. ${ }^{85}$ Two later ballad texts by Heywood also survive, one celebrating the marriage of Queen Mary to Philip of Spain (1554) and another, 'Against Slander and Detraction' (1562), which was printed just two years before Heywood's exile to Antwerp. By all evidence and accounts, Heywood was a gifted and versatile musician and entertainer of the very sort likely to be capable of improvisation.

As David Klausner suggests, 'we can divide the modes of improvisation in Renaissance theater into two: those planned by the playwright, and those unplanned. Planned improvisation was a staple of the period' - and much of this improvisation was assigned to Vice figures. ${ }^{86}$ Although Klausner does not specifically consider the question of musical improvisation within dramatic performances, his approach is instructive. In cases where singing is called for in the stage directions but neither the tune nor the song-text is specified, rather than assuming the music has been lost, we should consider the possibility that the playwright might instead have planned for the performer to improvise the cued song. Such a dilemma occurs in The Play of the Wether, where the text does indicate that the Vice, Mery Reporte, has two songs - one sung with others and one solo. The absence of both music and text for one song, and the absence of music for the other, affirms the likelihood that Heywood himself played Mery Reporte — and improvised Mery Reporte's songs. 
Before his first song, the Vice engages in bawdy dialogue with the idle Gentylwoman who desires to petition Jupiter for cloudy weather so that her complexion will not be damaged by the sun. Far from ushering her in, Mery Reporte attempts to seduce the woman and in fact hinders her suit, for which she wishes to speak with Jupiter alone. Weimann and Bruster emphasize the Vice figure's 'contrariety', 87 a feature embodied consistently by Mery Reporte. In the case of the Vice generally and Mery Reporte specifically, 'wherever relations of opposition presently exist, relations of seduction are put into play':88

Mery Report How spende ye the nyght?

Gentylwoman In daunsynge and syngynge

Tyll mydnyght and then fall to slepynge.

Mery Reporte Why, swete herte, by your false fayth, can ye sing?

Gentylwoman Nay, nay, but I love yt above all thynge.

Mery Reporte Now by my trouth for the love that I owe you,

You shall here what pleasure I can shew you.

One songe have I for you, suche as yt is,

And yf yt were better ye shold have yt, by gys!

Gentylwoman Mary syr, I thanke you even hartely.

Mery Reporte Come on, syrs, but now let us synge lustly.

[sd] Here they synge.

Gentylwoman Syr, this is well done, I hertely thanke you.

Ye have done me pleasure.

(844-855, and sd)

Mery Reporte's mischief is achieved through enchanting music that does the woman 'pleasure'. As Wisdom's Wyll well knew, 'the infinite powers of music may also allure and ravish the senses', and no one and 'nothing in the entire cosmos is immune to the charms of music', 89

I have provided the stage direction and the entire exchange between Mery Reporte and the Gentylwoman in order to demonstrate the confusion this passage in Wether has caused. Commentators claim that the unspecified song is a duet between Mery Reporte and the Gentylwoman. ${ }^{90}$ This may be the preference in performance, but this assertion is not supported by the surrounding dialogue. The Gentylwoman in fact states that she cannot sing, although she loves singing - most likely that of others. The Vice then invites the 'syrs' to sing with him. ${ }^{91}$ Whether these 'syrs' are other players or members of the audience is unclear, but it is clear that the Gentylwoman does not 
sing here; rather, the Vice and his cohorts do her 'pleasure', possibly with a song well-enough known that Heywood could improvise and expect that other players, singers, and even the 'syrs' among the audience would already know the tune.

In Wether's other Vice-song, Mery Reporte sings a solo. Late in the play, he goes out to fetch all the suitors while Jupiter makes a brief speech about the non-decision he is about to render. Mery Reporte returns with the suitors in tow, singing a solo in which he brags about his own persuasive skills and alludes devilishly to having 'bought' their souls, 'suche as they be':

\section{Mery Reporte and all the sewters entreth}

If I haddë caught them,

Or ever I raught them,

I wolde have taught them

To be nere me.

Full dere have I bought them,

Lorde, so I sought them,

Yet have I brought them

Suche as they be.

(sd and 1139-46)

Here again no tune is specified and a planned improvisation probably occurs. And once again singing is not specified either, but the rhyme scheme and metrics of these two quatrains are so different from the rhymed tetrameter couplets that prevail in the rest of this play that song is strongly indicated. At this critical moment in the drama, the Vice's song would have been syllabically set, possibly to a lively dance tune, in order to emphasize the Vice's flamboyant movements during his entrance. It is also noteworthy that the text is made up of short, crisp, non-Latinate words. The meter suggests that only one of the words — 'haddë' — was two-syllable; 'ever' would have been pronounced monosyllabically at the time. The rime-riche end-rhymes on '-aught/-ought them' would also make the song-text easy for the performer to remember. ${ }^{92}$

As the composer, playwright, and performer of the Vice, Heywood had control over both musical and theatrical improvisation, which might otherwise have gotten out of hand. As Klausner notes, the anxieties about improvisation that Hamlet expresses in his extended speech in the 'Mousetrap' scene in the First Quarto suggests that the clowns' improvisation was a recurrent problem that even risked disrupting performances: ${ }^{93}$ 
let not your Clowne speake

More then is set downe, there be of them I can tell you

That will laugh themselues, to set on some

Quantitie of barren spectators to laugh with them,

Albeit there is some necessary point in the Play

Then to be obserued: $\mathrm{O}$ t'is vile, and shewes

A pittifull ambition in the foole that vseth it.

Anxiety about controlling the improvising clown or fool thus extends to concern that a player's initiative, individuality, and 'ambition' might not only wreck the play but could also untune the social harmony of the theatrical space. Ambition, although soon to be considered a capitalist virtue, is still at this historical moment a vice.

Given the sensitive political situation in which Heywood operated, even allowed fools had to be very careful of what they said and did; under these circumstances, assigning improvisation - planned or unplanned - to other players might not have been at all wise. At one point in Wether, even Heywood/Mery Reporte himself comes right up to the edge of acceptable discourse. In the Vice's exchange with the Water Myller, Mery Reporte delivers a short speech loaded with obscene comparisons between milling and sexual intercourse, and about his own sexually unsatisfied spouse. In the 1529-30 court-performance context,

My wyfe sayth she will have a new myller

may allude comically to the royal marital crisis. But Mery Reporte is in control and recovers quickly; in a swift occupatio he moves on with the play:

But let yt passe — and now to our mater.

This passed-by 'yt' may hint at a planned improvisation judiciously abandoned.

\section{Signs of Vice in King Johan ${ }^{95}$}

Playwright and Protestant polemicist John Bale (1495-1563) was a Carmelite friar and contemporary of John Heywood, but, unlike Heywood, Bale left the Catholic church and converted to an extreme form of Protestantism 
in 1533. Bale was vocal in his radical religious views, which earned him initial favour and then exile in 1540 under Henry VIII, who also saw to it that several proclamations against the presentation of potentially transgressive 'enterludes', 'common plays', and 'stage plays' were issued in 1545 and 1547. ${ }^{96}$ Under Edward VI and his radical Protestant advisors, Bale returned to England and was installed as Bishop of Ossory in Ireland. Under Mary I, Bale was arrested, jailed, and again exiled; he returned again to England with Elizabeth I's accession.

Bale's plays and other writings contain apocalyptic themes, including the pope as the Anti-Christ, and a great deal of anti-Catholic and anti-celibate invective. While the Catholic Heywood's humorous Play of the Wether was performed early in the dark days of Henry VIII's divorce crisis, Bale's King Johan was a Protestant-polemical history play written and performed against the backdrop of the results of that crisis, namely, the deepening political and religious controversies of the late 1530s. Greg Walker points out that King Johan is the 'only extant play-text of the reign for which a precise date of [first] performance can be determined': the A-text of King Johan is datable on 'internal evidence' to 1538 , with a first performance of the play occurring before Thomas Cromwell during the Christmastide of 1538-39. ${ }^{97}$ Bale's two subsequent expansions of King Johan are also datable, albeit not as precisely: the B-text revision occurred between 1558 and 1560, and the b-text emendations sometime between Elizabeth's accession in 1558 and Bale's death in 1563. ${ }^{98}$ Thus, by the time of the first performance of King Johan, Henry had effected the split with Rome, divorced Katherine, and married Anne Boleyn.

In Bale's day, as in Shakespeare's and indeed our own, King John was widely considered a 'bad king' — the infanticide who lost England's foothold in France. Bale's play, however, is revisionist: the playwright effects a rehabilitation of 'bad' King John as a model of both the English crown's resistance to Rome's meddling and the crown's supremacy over the Church; this interpretation influences Shakespeare's representation of King John as well. Bale achieves King John's rehabilitation more by the portrayal of Catholic clerical figures as corrupt traitors than by the depiction of King John as particularly competent or clever. ${ }^{99}$ Bale's chief Vice-figure in King Johan is thus 'Sedicyon', whom Bale explicitly identifies as King John's Archbishop of Canterbury, Stephen Langton. Together, the Catholic conspirators constitute a threat to the new orthodoxy.

Unlike Heywood's mischievously seductive Vice Mery Reporte, Bale's Sedicyon/Langton is a maliciously seductive Vice who enacts his collusion 
with the play's minor Vices and draws the putatively virtuous King John into his web by means of song. As a playwright, Bale, who 'was particularly adept at exploiting music as an index of moral stature', deployed song as a sign of vice/Vice. ${ }^{100}$ In King Johan the songs of both the major and minor Vice figures emphasize the conspiratorial nature of the activities of recusant Catholics both inside and outside the drama. As Happé observes, in the interlude genre 'singing is by no means confined to Vice solos. There are many instances where a group of sinful characters express their wickedness in company with the Vice. ${ }^{101}$ In fact, in King Johan only two of the song texts indicate Vice solos. The first of these is sung late in the play by the deputy Vice 'Dyssymulacyon'. As is typical for Vice-song, even in the midst of tragedy, Dyssymulacyon's song is frivolous and jolly. From offstage, or perhaps from behind the screen in a great hall performance, Dyssymulacyon sings a well-known carol: 'Wassayle, wassayle, out of the mylke payle' (2087-91). Dyssymulacyon now enters as a seductive figure seeking to lead King John astray, but the virtuous king will only drink half the 'pocyon' the deputy-Vice presses on him.

The second of the two Vice solos in Bale's King Johan offers up a rare fragment of extant musical notation embedded in an interlude text. This time, the stage direction says 'Sedicyon entrat' and the chief Vice, Sedicyon/Langton, then enters singing 'Pepe, I see ye! I am glad I haue spyed ye' (2456-57). This measure of music is syllabically set and brings to mind the setting of the jingle tune assigned to the Vice Nicol Newfangle in Ulpian Fulwell's contemporary interlude Like Will to Like.

Whether 'Pepe, I see ye' is a fragment of a longer song or represents a brief musical setting to accompany the Vice's entrance is not known, as only one line of song-text is provided and only one measure of music survives. Furthermore, the music and song-text appear only in the b-Text emendations to the B-Text of King Johan, which is Bale's Elizabethan-era manuscript revision of his earlier Henrician play. In early performances of King Johan, a song may have been entirely improvised at this point. By the time of the b-text emendations, however, Bale may have wished to discourage improvisatory excesses by adding this musical prompt for use in productions by ambitious interluders who might be beyond his authorial control.

In addition to his brief solo, Sedicyon/Langton also engages in duets and quartets, which are this Vice's more common song vehicles and serve to emphasize the conspiratorial nature of the Vices' seduction project in this play. What is more, both of Sedicyon's duets involve invective parodies of Latin-texted chant. Bale has Sedicyon and Dyssymulacyon emphasize their 
loyalty to Rome by chanting in unison the incipit of the litany of saints and the 'Ora pro nobis', then the incipit of the 'Pater noster' (636-50) - all in Latin. Later, at lines 1789-1800, the second duet occurs, this time between Sedicyon/Langton and King John who together chant Protestant parodies of Latin mass texts which were still in use in Henry VIII's time. For instance, their 'Confiteor domino pape et omnibus cardinalibus' - 'I confess unto [my] lord the Pope and all the cardinals' (1789-1800) — is a parody of the 'Confiteor', the Catholic liturgical prayer of Confession in the old Latin rites: 'Confiteor deo omnipotenti et omnibus sanctis' - 'I confess unto almighty God and all the saints'. The desired effect of these associations and duets is, of course, to ridicule and discredit the Catholic faction. This singing also resonates with the audience's understanding of the nature and purpose of both profane secular music and profaned religious music. Either the Catholic Vices do not understand what they are singing, or they are proclaiming their true allegiance — namely, to the Church hierarchy rather than to God — by means of their corrupt Latin singing.

The Catholic Vices in King Johan are determined 'to subordinate the monarch and bring his ... sovereignty under their sway'. ${ }^{102}$ Toward this goal, the head-Vice Sedicyon/Langton leads the minor Vices - Dyssymulacyon/ Simon of Swynsett, Usurped Power/Pope Innocent III, and Private Wealth/ Cardinal Pandolphus - in two quartets of popular song. These quartets, at 11. $828 \mathrm{ff}$. and $1055 \mathrm{ff}$., are of unspecified 'merry' songs that the stage directions indicate are led by Sedicyon/Langton and sung by Sedicyon, Dyssymulacyon, Usurped Power, and Private Wealth together. At 1. 828, the stage direction says 'Here syng' and Usurped Power tells Sedicyon to launch the song:

Begyne thy self, than, and we shall lepe in amonge. (828)

After the song, Sedicyon replies

I wolde euer dwell here to haue such mery sporte. (829)

Thus, neither the music nor the song text are provided here, nor are they for the 'merry song' indicated in the stage directions at $1.1055 \mathrm{ff}$. In both of these instances, either the music was written and distributed separately from the play text or the singers were expected to collaborate in advance or to improvise for the performance. The overarching connection among all the Vice's songs in this play, however, is their catalytic role in the enactment of 
clerical depravity and of the attempts to seduce 'good' King John by separating him from his purported truth.

Over the twenty-six years between Bale's first version (1538) and final revision (1562-3) of King Johan, the anti-Catholic Protestant position that had alarmed Henry VIII had evolved into a new religious orthodoxy. In Bale's drama, the new religion's conception of devils and evil in the world emerges as something more menacing than mischievous. The Catholic Vices swirling around King Johan constitute a conspiracy of seductive signs; and as Baudrillard has noted,

seduction continues to appear to all orthodoxies as malefice and artifice, a black magic for the deviation of all truths, an exaltation of the malicious use of signs, a conspiracy of signs. ${ }^{103}$

\section{Pseudo-Classical Musical Revenge Tragedy: Horestes ${ }^{104}$}

Unlike Heywood and Bale, little is known of John Pickering, who may actually have been Sir John Puckering (1544-96) of Lincoln's Inn, Speaker of the House of Commons, and Lord Keeper of the Seal. ${ }^{105}$ The full title his 1567 pseudo-classical musical revenge tragedy, Horestes, is a mouthful: A newe Enterlude of Vice conteyning the History of Horestes with the cruell revengement of his Fathers death upon his one naturall Mother. The Vice is here announced as the main character, even though Horestes is the revenging hero of this interlude.

By 1567 , nearly forty years had passed since the improvised musical performances embedded in Heywood's Play of the Wether; with Horestes the interlude has evolved into something the twenty-first century observer might classify as musical theatre. The play's pretensions to classicism lend prestige; they also veil contemporary political allusion. This classicizing is undermined, perhaps even parodied, by the play's exuberant employment of popular song, through which Horestes mediates between the improvisational musical methods of Heywood and the more fully scripted songs and ballads of Shakespeare's stage. Horestes is just 1205 lines in length and contains four songs as well as cues for instrumental music, namely, drums and trumpet fanfares. Another strange feature of this interlude is that the Vice tends to speak in rhyme-royal stanzas - a high style normally reserved in earlier interludes for prologues or for important personages, like royals or royal sorts. The Vice 'drags' rhyme 
royal 'in the mud', ${ }^{106}$ while the revenging hero Horestes speaks chiefly in the clumsy rhymed heptameter line known as the fourteener. ${ }^{107}$

In Horestes, the Vice's role is to seduce the hero into the 'just' vengeance of his father Agamemnon's murder. Midway through the play, the character of the Vice reveals himself as Revenge, who is not only a dramatic character but also an abstract theological problem that Pickering's chief source, Lydgate's Troy Book, had settled in Orestes' favour. All four of the songs in Horestes are associated with villains, including the Vice Revenge; no scored music is provided for the song texts. In the first half of the play, the soldier Haultersyke enters singing 'Farre well, Adew' on his way to the gallows (306-29). His stage direction states 'entrithe and syngeth this song to the tune of "Have over the water to Floride" or "Sellingers Round" — the latter a well-known dance tune also arranged by Byrd. ${ }^{108}$ Clytemnestra and Egistus sing the duet, 'Lady, Lady' as well (538-601); stage directions call for them to 'enter ... singinge this song to the tune of 'King Salomon"' (sd 537). Each of these references calls for a tune well known to the players and to the audience.

In his discussion of the ambiguity posed by missing musical notation and the presence of song tags and cues, Bruce Smith maintains that

music in early modern England had a complicated relationship to graphic transcription. Despite treatises like Thomas Morley's A Plain and Easy Introduction to Practical Music (1597), the art of music was more typically transmitted person to person, singer to singer, lutenist to lutenist. Hence the sufficiency of the tag that accompanies most printed ballads 'to be sung to the tune of ...' ... For a literate historian, such a phrase all too often points toward silence. For musicians in early modern England, it pointed toward the known and the familiar, toward traces of sound that were already in the reader's brain, lungs, larynx, and mouth. ${ }^{109}$

In the second half of Horestes, the Vice sings both of his assigned songs, for neither of which has the music survived, but the meters provide 'traces' of rhythm and sound that suggest certain tune and tune types. The first of Vice's songs, 'Stand Back', is a four-stanza song with the rhyme scheme of ababccdd and a syllabic pattern of 8-4-8-4-8-8-8-8, which is not uncommon among ballads and popular songs of the time. This song is critical to the action of the play and to the hero Horestes' motivations for vengeance as well. In the third verse of the song the Vice, who has already seduced Horestes, reveals himself to be none other than 'Revenge' personified: 
But in this stower who beares the fame

But onely I?

Revenge, Revenge wyll have the name,

Or he wyll dye.

I spare no wight, I feare none yll,

But with this blade I wyll them kyll,

For when myne eare is set on fyare

I rap them, I snap them — that is my desyare.

$(664-71)$

The Vice is clear: he has seduced Horestes to satisfy his own perverse desire to see revenge realized.

Pickering indicates that the Vice is to sing this song 'to the tune of The Paynter', by which the playwright probably meant the ballad 'The Paynter in his Pryntyshod', the text for which was printed in 1565-6. The ballad tune does not survive, but the title is suggestive: the Vice/Revenge sings about murder to a tune that allusively highlights his own craft while it celebrates the corrupt apprenticeship into which he has initiated Horestes. Like Falstaff's threat to supply new texts to old 'filthy tunes', ${ }^{110}$ the Vice here chooses a tune whose prior meaning will resonate while it accumulates new significance with its new words. For Axton's edition of Horestes, John Buttrey set 'Stand Back' to a lively branle that he adapted from Dublin Virginal MS (no. 28). Simpson suggests the tune of the ballad 'Cock Lorrel' would also be appropriate as it also fits the metrical pattern of 'Stand Back' neatly. ${ }^{111}$

Revenge's other song, which is the final song in Horestes, is the threestanza tune 'A Newe Master, a Newe!' in which Revenge celebrates the arrival of Menelaus with Helen. The Vice, who had urged Horestes on to vengeance, now sings a maliciously gleeful lyric, likely set in a boisterous syllabic style, indicating his joy that the object of his seduction, Horestes, will be the victim of further revenge when Menelaus appears and seeks to avenge his dead brother, Agamemnon. As Axton observes, Caliban's 'Farewell, Master, farewell, farewell!' in The Tempest (2.2.174) provides a later echo of Horestes' Vice's master-greeting song: ${ }^{112}$

A newe master, a newe!

No lenger I maye

A byde; by this daye

Horestes now doth rew. 
A newe master, a newe!

And yt was not yll

His mother to kyll?

I pray you, how saye you?

A newe master, a newe!

Now ites to late

To shut the gate;

Horestes gines to rew! ${ }^{113}$

(849-60)

The Vice Revenge's delight is thwarted, however, when Horestes is not killed. The hero is instead redeemed and crowned by Dewty and Truth (1145-46).

\section{Exit the Vice}

Although Revenge seduces Horestes and the manipulated hero enacts the vengeance promoted by the Vice, virtue triumphs with Horestes' vindication and coronation. The defeated Vice exits the drama with a sullen rhyme-royal defeat speech — or song — that is both concessionary and cautionary:

Well, far you well, for I must be packinge.

Remembar my wordes, and beare it in mynde:

What, suffer the myll a whyle to be clackinge,

Yf that you intend aney ease forto fynde;

Then wyll they be to you both lovinge and kinde.

Farwell Cosen Cutpursse, and be ruled by me,

Or elles you may chaunce to end on a tre.

$(1114-20)$

The Vice intends to go far in attempting to obliterate the pleasure the audience has taken in the foregoing musical seduction. But at such epilogic moments the audience 'is not being asked to forget what they have just witnessed, but rather to remember it', which they will with lingering pleasure. ${ }^{114}$

Among the last of the singing Vices, Iago uses the tavern song 'And Let me the Cannikin Clink' to advance his elaborate revenge project by seducing and ruining the sober Cassio with drink (2.3.64-93). ${ }^{115}$ As David Lindley asserts, 'popular music is Iago's persuasive means to entice Cassio with the illusion of conviviality and belonging to the crowd'. The audience, too, is led astray by 
the pleasure of the song: 'Iago seduces us, briefly at least, into complicity with his scheming through the agency of song. ${ }^{116}$ As a singing seducer, Iago

knows how to let the signs hang. He knows that they are favourable only when left suspended and will move of themselves toward their appointed destiny. $\mathrm{He}$ does not use the signs up all at once, but waits for the moment when they will all respond, one after the other, creating an entirely unique conjuncture of giddiness and collapse. ${ }^{117}$

And typically for the 'old Vice' the signs Iago has created collapse upon him, as well. In this very way, throughout the interlude genre the Vice ritualizes the signs within his own seductive 'game without end in which the signs participate spontaneously, as if from a continuous sense of irony'. ${ }^{118}$

The Vice's resonant transgressivity is essential to understanding the achievements of the personated Vice as a singer and player — and as a character - and the audience's engagement with the Vice's seductive performance, through which he originally and ultimately represented the early English audience's own 'literal and archetypal enemy ... the Devil'. ${ }^{119}$ All of these signs combine with the Quintilianist understanding of the seductive power of theatrical music to create, contain, and sustain singing as a sign of vice.

\section{Notes}

For their unstinting intellectual generosity, to Stephen Buhler and Pamela Starr I dedicate this essay. Timothy McGee, Peter Lefferts, Kurt Knecht, Douglas Bruster, and the anonymous readers for Early Theatre provided helpful advice and frank critiques for which I am deeply grateful. My thanks are due as well to the members of the English Renaissance Music and Text seminar at the University of NebraskaLincoln and to the participants in the Devil in Society in the Premodern World conference at the University of Toronto.

1 This title echoes David Klausner's 'The Improvising Vice in Renaissance England', in Timothy J. McGee (ed.), Improvisation in the Arts of the Middle Ages and Renaissance (Kalamazoo, 2003), 273-85. Klausner's acute distinction between 'planned' and 'unplanned' improvisation (275) particularly influences my view of John Heywood's performativity.

2 Richard Leppert, The Sight of Sound: Music, Representation, and the History of the Body (Berkeley, 1993), 28. 
3 Among this scholarship are several works by Richard Rastall, including his $\mathrm{PhD}$ thesis, Secular Musicians in Late Medieval England (Manchester University, 1968) available electronically at <www.reed.utoronto.ca/emus.html>, and his magisterial two-volume work The Heavens Singing (vol. 1) and Minstrels Playing: Music in Early English Religious Drama (vol. 2) (Cambridge, 2001). JoAnna Dutka's Music in the English Mystery Plays (Kalamazoo, 1980) is invaluable in its highly specific and detailed analysis of the music and its functions within English religious drama.

4 Peter Happés Song in Morality Play and Interludes (Lancaster, 1991) is a thorough work which catalogues and categorizes songs, song references, and stage directions for singing and for scored music in the interludes, but stops short of theorizing the singing in moralities and interludes. See also Darryll Grantley, English Dramatic Interludes, 1300-1580: A Reference Guide (Cambridge, 2004), which cites in brief much of the instrumental and vocal music that is cued or texted or for which a rare musical score is supplied.

5 Tim Carter, 'Secular Vocal Music', in Roger Bray (ed.), The Blackwell History of Music in Britain: The Sixteenth Century (Oxford, 1995), 147-209; Carter observes that 'the absence of a print culture for native secular music in Britain, at least until the last two decades of the sixteenth century, has significant ramifications' (148).

6 Richard Rastall, 'Music in the Cycle Plays', M.G. Briscoe and J.C. Coldewey (eds), Contexts for Early English Drama (Bloomington, 1989), 193, 210.

7 In his play The Four Elements (printed c 1520) John Rastell himself printed the score of a three-part song, 'Tym to Pas', which represents the first known and extant example of music printing in Britain; the tune is very close to that 'Adew Madam' in the Henry VIII MS, which John Stevens (Music and Poetry in the Early Tudor Court [London, 1961], 131) believes to be at least in part the work of John Heywood (Rastell's son-in-law). In Ulpian Fulwell's Like Will to Like (printed 1568), the Vice Nicol Newfangle sings a scored jingle ('Trim Merchandise, Trim, Trim'). The score for a three-part song, of which there are two in the play, also survives (Q2 F2v), regarding the performance of which see Andrew Sabol, 'A Three-Man Song in Fulwell's Like Will to Like at the Folger', Renaissance News 10 (1957), 139-42.

8 Richard Rastall, 'The Sounds of Hell', Clifford Davidson and Thomas Seiler (eds), The Iconography of Hell (Kalamazoo, 1992), 122-4.

9 Suzanne Westfall, "'An example of courtesy and liberality”: great households and performance', Jane Milling and Peter Thomson (eds), The Cambridge History of British Theatre, 3 vols (Cambridge, 2004), 1.201. See also Westfall's groundbreaking study Patrons and Performance: Early Tudor Household Revels (Oxford, 1990).

10 David Bevington, From Mankind to Marlowe (Cambridge, MA, 1962), 11; Peter Happé, Tudor Interludes (Baltimore, 1972), 11. 


\section{Maura Giles-Watson}

11 For the discussion, see, for example, Jean-Paul Debax, 'Complicity and Hierarchy: A Tentative Definition of the Interlude Genre', in Peter Happé and Wim Hüsken (eds), Interludes and Early Modern Society (Amsterdam, 2007), 23-43; Nicholas Davis, 'The Meaning of the Word "Interlude”: A Discussion', Medieval English Theatre 6 (1984), 5-15; and Edward Burns, Character: Acting and Being on the Premodern Stage (New York, 1990), 52-4.

12 For a detailed discussion of great hall performance practices, see T.W. Craik, The Tudor Interlude: Costume, Stage, and Acting (Leicester, 1958; rpt. 1967), 9-26; and Westfall, Patrons and Performance.

13 Julia Craig-McFeely, 'The Signifying Serpent: Seduction by Cultural Stereotype in Seventeenth-Century England', in Linda P. Austern (ed.), Music, Sensation, and Sensuality (London, 2002), 300; see also Leppert, The Sight of Sound, 28.

14 Happé, Tudor Interludes, 11.

15 The 'mynstrallys' in Wisdom are indicated at sd 692 (for Mynde); 724 sd (for Understondyng); and (for Wyll) at sd 752 and 757-8. Quotations from Wisdom are from the text edited by Greg Walker in Medieval Drama: An Anthology (Oxford, 2000).

16 Quotations from Mankind are from the text edited by Greg Walker in Medieval Drama: An Anthology (Oxford, 2000). At another point, the Vice New Gyse commands his fellow Vices: 'And how, mystrellys, pley pe comyn trace!' (1. 72). In the introduction to their new edition of Everyman and Mankind (London, 2009), editors Douglas Bruster and Eric Rasmussen observe that at 1.72 New Gyse is calling upon the minstrels to dance, but at 11. 451-3 Myscheff calls upon Nought to perform musical mistrelsy. On the most recent evidence, Bruster and Rasmussen note that it seems safest to call Mankind a play of the 1470s' (29).

17 For example, William Langland, Piers Plowman: A New Edition of the C-Text, ed. Derek Pearsall (Exeter, 2008), on the 'moral ambiguity of' and 'hostility to minstrels' that emerges in the poem (24); John Southworth, The English Medieval Minstrel (Woodbridge, 1989), objects to the notion of itinerant minstrels as 'wandering' and asserts their 'mobility' instead (4-9); also see Richard Rastall, 'Minstrelsy, Church and Clergy in Medieval England', Proceedings of the Royal Musical Association 97 (1970-71), 83-98.

18 R.C. Jones, 'Dangerous Sport: The Audience's Engagement with the Vice in the Moral Interludes', Renaissance Drama ns 6 (1976), 46; Hans-Jürgen Diller, 'Theatrical Pragmatics: The Actor-Audience Relationship from the Mystery Cycles to the Early Tudor Comedies', Comparative Drama 23 (1989) 164; Burns, Character: Acting and Being, 56-7.

19 Rastall, 'The Sounds of Hell', 103, 109; Rastall also notes that coal is further 'significant as symbolic of hellish business' (102-3). 
20 Raymond Monelle, Linguistics and Semiotics in Music (London, 1992), 316.

21 Ibid.

22 Ibid.

23 Robert Weimann and Douglas Bruster, Shakespeare and the Power of Performance (Cambridge, 2008), 5.

24 Ibid.

25 Happé, Song in Morality Play and Interludes, 4.

26 Burns, Character: Acting and Being, 53.

27 John D. Cox, The Devil and the Sacred in English Drama, 1350-1642 (Cambridge, 2000), 52.

28 Cox, The Devil and the Sacred, 58. See also John D. Cox, 'Devils and Vices in English Non-Cycle Plays: Sacrament and Social Body', Comparative Drama 30 (1996), 188218; in the context of the early moral plays Cox notes that with regard to Mankind the 'devil and vices clearly work toward the same end in this play' (202).

29 Rastall, 'The Sounds of Hell', 113; for the association of music with 'seductive courtly pursuits' see John Stevens, 'Music in Medieval Drama', Proceedings of the Royal Musical Association 84 (1957-8), 89. For a succinct discussion of sixteenth-century English perspectives on the relationship of good and bad character to good and bad music, see David Lindley, Shakespeare and Music (London, 2006), 44-9.

30 Jean Baudrillard, Seduction, trans. Brian Singer (Montreal, 1990), 2.

31 Ibid, 76.

32 Ibid, 81.

33 Ibid, 83 (parentheses in original).

34 Zygmunt Bauman, 'Postmodernity, or Living with Ambivalence', in Joseph Natoli and Linda Hutcheon (eds), A Postmodern Reader (Albany, 1993), 11.

35 For the softening qualities of music see Linda P. Austern, "AAlluring the Auditorie to Effeminacie": Music and the Idea of the Feminine in Early Modern England', Music and Letters 74 (1993), 343-54.

36 Baudrillard, Seduction, 81.

37 Happé, English Drama Before Shakespeare (Harlow, 1989), 138-9. Regarding music as a structural feature of drama see Dutka, Music in the English Mystery Play, 7-8; Nan Cooke Carpenter, 'Music in the Secunda Pastorum', in J. Taylor and A.H. Nelson (eds), Medieval English Drama (Chicago, 1972), 213-14.

38 Linda P. Austern, "Art to Enchant": Musical Magic and its Practitioners in English Renaissance Drama', Journal of the Royal Musical Association 115 (1990), 196. Austern is referring to the anonymous In Praise of Musicke (London, 1586; sTC 2/20184). 
39 Jean Alter, A Sociosemiotic Theory of Theatre (Philadelphia, 1990), 31-2. Weimann and Bruster introduce Alter's approach into the discussion of Vices and clowns in Shakespeare and the Power of Performance, 46, 66, and elsewhere.

40 On the relationship of the earlier Vice to Elizabethan clowns and fools, see David Wiles, Shakespeare's Clown: Actor and Text in the Elizabethan Playhouse (Cambridge, 1987), esp. 1-11.

41 William Shakespeare, Twelfth Night, F1 (1623); sтC (2nd ed.)/22273; вево, image 147.

42 I use 'actorly' as the visual arts use 'painterly', i.e. for techniques that are intentionally rendered visible, rather than hidden, in art.

43 Stevens, 'Music in Medieval Drama', 83 (emphases in the original).

44 Weimann and Bruster, Shakespeare and the Power of Performance, 66.

45 Stevens, 'Music in Medieval Drama', 83; Richard Rastall, 'Alle Hefne Makyth Melody', in Paula Neuss (ed.), Aspects of Early English Drama (Cambridge, 1983), 4-5.

46 Falstaff's complex performativity is most recently and extensively analyzed by Weimann and Bruster, Shakespeare and the Power of Performance, esp. 152-9; Falstaff's Vice-like characteristics are discussed by Douglas Hayes, Rhetorical Subversion in Early English Drama (New York, 2004), 91-100.

47 Except by Stephen Buhler in his dramaturgical work on the Flatwater Shakespeare Company's 2009 production of Merry Wives of Windsor, directed by Bob Hall. In performance, Falstaff (Joel Story) sang all of the indicated song references and snatches. Ross W. Duffin, Shakespeare's Songbook (New York, 2004) provided the musical scores.

48 This occurs throughout the play, for example, 'Come to me soon' from 'Dulcina' (both Qs) 2.2 and 3.5; his strategic misquotation of 'Fortune my Foe' as 'Fortune thy foe', (F) 3.3; and his reference to 'Green-sleeves', (F) 5.5. Interestingly, both Salieri and Verdi were alert to Falstaff's musicality in this play; each adapted Merry Wives for the operatic stage.

49 Adorno, 'Little Heresy', R. Lepperts (ed.), S. Gillespie (trans.), Essays on Music, (Berkeley, 2002), 318.

50 Adorno, 'On the Social Situation of Music', Essays on Music, 395-6.

51 William Shakespeare, Henry the Fourth Part I, G. Blakmore Evans (ed.), The Riverside Shakespeare (Boston, 1997).

52 Satirical or scurrilous jigs were commonly written to existing music in precisely the way that Falstaff announces. On the jig genre, see C.J. Sisson, The Lost Plays of Shakespeare's Age (Cambridge, 1936), 125-56, and Charles R. Baskervill, The Elizabethan Jig and Related Song Drama (Chicago, 1929), esp. 164-218. 
53 Quintilian, Inst Ora 1.10.31: 'quae nunc in scaenis effeminata et inpudicis modis fracta non ex parte minima si quid in nobis virilis roboris manebat excidit'. Although neither treats Quintilian's contribution, for analyses of gendered perspectives on music in the early modern period see Linda P. Austern, "Alluring the Auditorie to Effeminacie"', 343-54, and R. Hohl Trillini, 'The Gaze of the Listener', Music and Letters 89 (2008), 1-17.

54 Stephen Gosson, Plays Confuted in Five Actions. Printed 1582; stc/384:21. Eebo, image 42 .

55 Ibid, image 57.

56 Anon., In Praise of Musicke, Printed 1586. stc2/20184. For an illuminating discussion of Case's treatise and the ethical debate over the use of music, see Wegman, The Crisis of Music in Early Modern Europe (New York, 2005), 59-66.

57 Leppert, The Sight of Sound, 27.

58 Duffin, Shakespeare's Songbook, 207.

59 Among them, for example, David Bevington (ed.), The Complete Works of William Shakespeare (New York, 2009), and G. Blakemore Evans and J.J.M. Tobin (gen. eds), The Riverside Shakespeare (Boston, 1997).

60 In the First Folio, stage directions do mark other Clown/Feste songs in Twelfth Night, for example, at (F) 2.3 'Clowne sings'; at (F) 2.4 'Musicke/ The Song'; and at (F) 5.1 'Clowne sings'.

61 Duffin, Shakespeare's Songbook, 207.

62 Weimann and Bruster, Shakespeare and the Power of Performance, 99.

63 Tia DeNora, After Adorno: Rethinking Music Sociology (Cambridge, 2003), 57.

64 George Wapull, The Tyde Taryeth no Man. Printed 1576. sтс2/25018.

65 First performed 1529-30; first printed 1533. Quotations from Heywood's The Play of the Wether are from R. Axton and P. Happé (eds), The Plays of John Heywood (Cambridge, 1991).

66 This entry appears in 1519-20: Fiona Kisby, 'Royal Minstrels in the City and Suburbs of Early Tudor London: Professional Activities and Private', Early Music 25 (1997), 205; Stevens, Music and Poetry, 267-8; Andrew Ashbee, 'Groomed for Service: Musicians in the Privy Chamber at the English Court, c 1495-1558', Early Music 25 (1997), 185-90, 193-7, esp. 190.

67 Kisby, 'Royal Minstrels', 205. On Heywood's other appearances in the records, including his 1557 pensioning, see Andrew Ashbee, Records of English Court Music 9 vols (Aldershot, 1986), 8.12.

68 Thomas Whythorne, Autobiography, ed. James M. Osborn (Oxford, 1961), 13.

69 David Bevington, Tudor Drama and Politics (Cambridge, 1968), 65.

70 Greg Walker, Writing Under Tyranny (Oxford, 2005), 100-2. 
71 Kisby, 'Royal Minstrels', 201.

72 Greg Walker, Plays of Persuasion (Cambridge, 1991), 133.

73 Ashbee, 'Groomed for Service', 193.

74 Stevens, Music and Poetry, 113.

75 Ibid, 258.

76 Even in Heywood's case such a score is more likely to have been written than printed. Carter, 'Secular Vocal Music' (147-8), notes that printed music was rare in Britain before the 1580s.

77 Simon Palfrey and Tiffany Stern, Shakespeare in Parts (Oxford, 2007), 7. Although Palfrey's and Stern's findings derive from the later public theatre and they do not discuss musical parts per se, their approach is intriguingly suggestive of the second possibility: 'Rather than thinking of plays as finished books, we might better conceive of them as loose-leaf sheets, commissioned, or swapped, or shuffled with facile aplomb ... The prime material of circulation was the part'. I thank Douglas Bruster for bringing this innovative work to my attention.

78 Reinhard Strohm, 'Unwritten and Written Music', Tess Knighton and David Fallows (eds), Companion to Medieval and Renaissance Music (New York, 1992), 229.

79 Stevens, Music and Poetry, 282.

80 Walter Woodfill, Musicians in English Society (1963; rpt New York, 1969), 177; John Izon, 'Italian Musicians at the Tudor Court', The Musical Quarterly 44 (1958), 330-2.

81 Whythorne, Autobiography, 13 (spelling modernized). Whythorne wrote his autobiography around 1576; it was first published in 1961. See also Howard Brown and Keith Polk, 'Instrumental Music, c 1300-c 1520', in Reinhard Strohm and Bonnie J. Blackburn (eds), Music as Concept and Practice in the Late Middle Ages (Oxford, 2001), 127; and John Caldwell, The Oxford History of English Music (Oxford, 1991), 327-30.

82 Whythorne, Autobiography, 244. For a discussion of the shift in the perceptions and self-perceptions of different categories of musicians - a shift that occurs in England in the sixteenth century, but somewhat earlier on the continent - see Rob Wegman, 'From Maker to Composer: Improvisation and Musical Authorship in the Low Countries, 1450-1500', Journal of the American Musicological Society 49 (1996), 409-79; and Timothy J. McGee, 'The Fall of the Noble Minstrel: The SixteenthCentury Minstrel in a Musical Context', in Leeds Barrol (ed), Medieval and Renaissance Drama in England 7 (1995), 98-120.

83 Wegman, 'From Maker to Composer', 411.

84 Namely, 'What harte can thincke' (ms Add. 4900) and 'All a green willow' (Ms Add. 15117); see also Stevens, Music and Poetry, 282, 293. 
85 Stevens, Music and Poetry, 131. David Fallows ('Henry VIII as a Composer', in C. Banks (ed.), Sundry Sorts of Music Books [London, 1993], 27-39) does not take up this possibility, however, and notes numerous compositional blunders a professional composer would have been unlikely to make. John Caldwell notes that 'though Henry himself was a performer as well as a composer, this music will most often have been played and sung ... by professional musicians' (Oxford History of English Music, 258).

86 Klausner, 'The Improvising Vice', 275-6.

87 Weimann and Bruster, Shakespeare and the Power of Performance, $29 \mathrm{ff}$.

88 Baudrillard, Seduction, 104.

89 Austern, 'Art to Enchant', 195.

90 For instance, Happé, English Drama Before Shakespeare, 123.

91 Compare Nowadays's address to the 'sers' in Mankind (332), above.

92 For an instructive discussion of meter and memory in a different musical context, see A.M. Busse Berger, 'Mnemotechnics and Notre Dame Polyphony', Journal of Musicology 14 (1996), 263-98.

93 Klausner, 'The Improvising Vice', 278-9.

94 William Shakespeare, Hamlet, Q1 (1603), F2r; sтс2/22275; евво, image 18.

95 Quotations from King Johan are from the edition by B.B. Adams (San Marino, 1969).

96 Glynne Wickham, Herbert Berry, and William Ingram, English Professional Theatre, 1530-1660 (Cambridge, 2000), 30-2.

97 Leininger, 'Evangelical "Enterluders": Patronage and Playing in Reformation England', Reformation and Renaissance Review 4 (2002), 78.

98 Walker, Plays of Persuasion, 171, 173; for textual criticism, see also the thorough introductions to Bale's King Johan in the edition by B.B. Adams and in volume 2 of P. Happé (ed.), The Complete Plays of John Bale, 2 vols (Cambridge, 1985-6).

99 For the 'elaboration of the Vice tradition' in King Johan, see, The Complete Plays of John Bale, 2.10-11.

100 Westfall, Patrons and Performance, 103.

101 Happé, English Drama before Shakespeare, 139.

102 Dermot Cavanaugh, 'Reforming Sovereignty: John Bale and Tragic Drama', in Happé and Hüsken (eds), Interludes and Early Modern Society, 198.

103 Baudrillard, Seduction, 2.

104 Quotations from M. Axton (ed.), Horestes are from Three Tudor Classical Interludes (Cambridge, 1982).

105 Three Tudor Classical Interludes, 4. 
106 J.E. Bernard, The Prosody of the Tudor Interlude, Yale Studies in English 90 (1939; rpt. New York, 1969), 136.

107 Bernard, The Prosody of the Tudor Interlude, 3, 135.

108 Claude M. Simpson, The British Broadside Ballad (New Brunswick, 1966), 643-6.

109 Bruce R. Smith, The Acoustic World of Early Modern England (Chicago, 1999), 112.

110 1Henry IV, 2.2.46.

111 Simpson, British Broadside Ballad, 132 n 6.

112 Pickering, Horestes, 158.

113 Audio for Buttrey's arrangements of 'Stand Back' and 'A Newe Master' are available on the $2006 \mathrm{CD}$ by the Mignarda lute duo, Edward De Vere and his Circle: My Lord of Oxenford's Mask <http://mignarda.eglanteria.com>.

114 I thank Rhonda Garelick for this insight.

115 William Shakespeare, Othello, David Bevington (ed.), The Complete Works of Shakespeare, (New York, 2009). Echoes of the Vice's activities as a drink tempter are heard as late as Comus in Milton's Mask at Ludlow Castle (1634), 11. 659sd ff. Roy Flannagan (ed.) The Riverside Milton (Boston, 1998). Interestingly, Comus also describes himself and his cohorts in terms of enchanting music: 'We that are of purer fire/ Imitate the starry quire' (11. 111-12).

116Lindley, Shakespeare and Music, 152

117 Baudrillard, Seduction, 109.

$118 \mathrm{Ibid}, 103$.

119 Cox, The Devil and the Sacred, 216. 